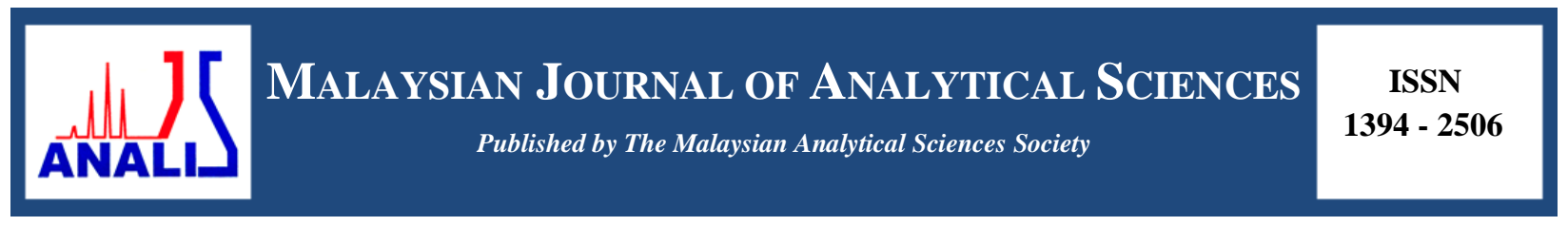

\title{
EFFECTS OF DIFFERENT GRINDING METHODS ON MORPHOLOGICAL, TEXTURAL PROPERTIES AND PASTING PROFILES OF MR220 RICE FLOUR
}

\author{
(Kesan Kaedah Pengisaran yang Berbeza terhadap Morfologi, Sifat Tekstur dan Profil Pempesan \\ Tepung Beras MR220)
}

\author{
Noorlaila Ahmad ${ }^{1}$, Asmeda Rajab ${ }^{1}$, Norziah Mohd Hani ${ }^{2}$ \\ ${ }^{I}$ Department of Food Technology, Faculty of Applied Sciences, \\ Universiti Teknologi MARA, 40450 Shah Alam, Selangor, Malaysia \\ ${ }^{2}$ Food Technology Department, School of Industrial Technology, \\ Universiti Sains Malaysia, 40450 Minden, Penang, Malaysia
}

*Corresponding author: dnoorlaila@salam.uitm.edu.my

Received: 24 February 2015; Accepted: 27 October 2015

\begin{abstract}
Three different grinding techniques (dry, semi-wet, and wet) were employed in rice flour production. Investigation on the effects of the grinding techniques on starch damage percentage, particle size distribution, pasting profiles, morphological and textural properties of rice flours produced were evaluated. Wet grinding resulted in significantly $(\mathrm{p}<0.05)$ has lower percentage of damaged starch $(3.24 \%)$ than other grinding methods. Morphological studies (microscopy and particle size analysis) have reflected significant differences among rice flours granule shapes. The granules displaying different shapes of polygonal, round and angular forms, with some as an individual granule while others tend to attached together. Wet grinding technique also yielded flour that exhibit significantly $(\mathrm{p}<0.05)$ with higher gel hardness $(16.62 \mathrm{~g})$. Pasting profiles showed that pasting temperature for rice flour produce using these three grinding methods varied between $80.15-80.42{ }^{\circ} \mathrm{C}$. Results revealed that the three grinding techniques clearly affected the physicochemical properties of rice flour. The results from this study play an important role in the selection criteria of rice flour with desirable pasting and textural properties for manufacturing rice-based product.
\end{abstract}

Keywords: Grinding techniques, particle size, pasting profiles, rice flour, starch damage

\begin{abstract}
Abstrak
Tiga jenis teknik pengisaran (kering, separa basah, dan basah) telah digunakan dalam penghasilan tepung beras. Kajian ke atas kesan teknik pengisaran pada peratusan kerosakan kanji, taburan saiz partikel, profil pempesan, sifat morfologi dan tekstur tepung beras yang dihasilkan telah dianalisa. Pengisaran basah menyebabkan peratusan kanji rosak $(\mathrm{p}<0.05)$ lebih rendah secara signifikan $(3.24 \%)$ berbanding kaedah - kaedah pengisaran lain. Kajian morfologi (mikroskopi dan analisis saiz zarah) telah menunjukkan perbezaan yang signifikan antara tepung beras dari segi saiz dan bentuk granul yang terhasil. Granul memaparkan bentuk berlainan seperti poligon, bulat dan bentuk bersudut, samada wujud sebagai granul sendirian ataupun berkluster. Teknik pengisaran basah juga menghasilkan perbezaan yang signifikan $(p<0.05)$ berbanding teknik pengisaran lain dari segi kekerasan gel yang lebih tinggi (16.62 g). Profil pempesan menunjukkan suhu pempesan untuk tepung beras yang dihasilkan menggunakan ketiga - tiga kaedah pengisaran berada dalam julat antara $80.15-80.42{ }^{\circ} \mathrm{C}$. Hasil kajian dengan jelas menunjukkan bahawa tiga teknik pengisaran memberi kesan kepada ciri - ciri fizikokimia tepung beras. Hasil kajian ini sangat penting dalam menentukan kriteria tepung beras berdasarkan sifat dan sifat tekstur yang dikehendaki untuk pembuatan produk berasaskan beras.
\end{abstract}

Kata kunci: Teknik pengisaran, saiz partikel, profil pempesan, tepung beras, kerosakan kanji 


\section{Introduction}

Rice (Oryza sativa L.) has been consumed by humans for almost 5000 years. Rice is a staple food for Malaysians, with current intake of rice is approximately 2.8 million tons [1]. The rice paddy will be milled in order to obtain white or brown rice grains. Rice flour is widely used to produce many kinds of food; hence it is crucial to produce flour with fine size particle for applications in various types of food products. Rice has been shown to vary widely in its cooking [2] and eating quality [3], depending on variety and type of rice.

Grinding is a unit operation widely used in the food industry. In developing countries, it is the common method for food powder processing [4]. In general, grinding is one part of a larger set of operations involved in the process of size reduction [5]. Dry grinding uses no water, need few manpower, and thus require low cost in production. While semi-wet grinding consume small amount of water for the soaking process and use one particular machine. As compared to dry and semi-wet grinding process, wet grinding involved usage of more than one machine, more manpower and more water thus generate higher cost as compared to others.

Flour characteristics as result from grinding process, such as particle size and damaged starch level; determine its suitability for specific end-products [6,7]. When starch is heated continuously in excess water with stirring, starch granules swell irreversibly, accompanied by leaching of amylose and possibly solubilisation of amylopectin, resulting in the formation of paste. To a certain extent, the starch pasting behaviour determines rice cooking quality and functionality, since starch is the main component in rice [8].

This study aim to investigate the effect of different grinding practices in rice utilization, and filling the gap by providing specific information on physicochemical properties and pasting profiles of rice flour from Malaysian variety which is still lacking. The information is essential for predicting their functionality and subsequent end-use in foods. In addition, the present study were conducted to compare the performance of the dry grinding, semi-wet grinding, and wet grinding processes in order to improve the eating quality of rice or for selection of specific behavior/characteristic by using the appropriate grinding method.

\section{Raw material}

\section{Materials and Methods}

Malaysian rice variety of MR220 was obtained from Malaysian Agricultural Research and Development Institute (MARDI) Pulau Pinang, Malaysia. This rice variety was grown from genes seeds obtained from cross breeding of parents MR151 and MR137. Rice paddy was harvested at maturity, cleaned, dehulled and milled to obtain milled rice grains. Only whole rice grain without any physical damage or insect infestation was selected for analysis. The chemicals were obtained from the commercial scientific suppliers. The assay kit of damaged starch content was purchased from Megazyme International Ltd. (Ireland).

\section{Grinding machines}

For dry and semi-wet grinding process, a hammer mill (Rotary Type CNS, Taiwan) was used. For wet grinding, hammer mill and stone mill (Wet Grain Grinder, WGG 254, Malaysia) were used.

\section{Rice flour preparation}

Sample was prepared using three different grinding techniques. In the dry grinding technique, the rice grains obtained were directly ground into rice flour for two cycles using the hammer mill. In the semi-wet grinding technique, rice grains were soaked in water for 8 hours at rice to water ratio of 1:1 (w/v). The excess water was then drained and the rice grains were allowed to dry at room temperature before grinding with the hammer mill. In the wet grinding technique, rice grains were ground using stone mill with excess water after subjected to soaking for 8 hours at rice to water ratio of $1: 1(\mathrm{w} / \mathrm{v})$. The slurry obtained was filtered pressed and the semi dried residue was collected. The dried sample was reground using hammer mill. All flour samples were dried in a cabinet dryer to obtain moisture content of less than $15 \%$ prior to the analysis. Flour samples were sieved through a 100 mesh sieve (Retsch, Germany) and packed in air tight plastic container until further use. 


\section{Starch damage determination}

The damaged starch content in the flour samples was determined using the starch damage assay kit by Megazyme International Ireland in accordance with the approved method 76-31 of the American Association of Cereal Chemists (AACC) [9].

\section{Particle size distribution}

The particle size distribution and average particle size of rice flour samples were analyzed by using the Mastersizer (Malvern Instrument, UK) fitted with Scirocco 2000 unit for the dry samples at a refractive index of 1.54. The equipment was equipped with a laser beam for detection.

\section{Scanning electron microscopy}

The microstructure of rice flour was observed using a scanning electron microscope (SEM, JSM-6610, JEOL, Tokyo, Japan). The rice flour sample was coated with platinum and dispersed on a SEM specimen stub with doublesided conductive tape. The SEM was operated at an accelerated voltage of $10 \mathrm{kV}$.

\section{Pasting profiles}

The pasting profiles of rice flour were evaluated using the Rapid Visco Analyzer (RVA, Newport Scientific, Australia) following the AACC method 61-02 [10]. Parameters including pasting temperature (PT), peak viscosity $(\mathrm{PV})$, final viscosity $(\mathrm{FV})$, breakdown viscosity $(\mathrm{BV})$, setback viscosity $(\mathrm{SB})$, trough $(\mathrm{T})$ and peak time were calculated from the pasting curve assisted by the Thermocline software program for Windows (TCW).

\section{Gel texture}

The gelatinized mixture in the canister, after the RVA measurement was being used to measure gel hardness. The paddle was removed immediately and the paste in the canister was covered by parafilm and left at room temperature for 1 hour to allow formation of a solid gel. Texture of the gel was then determined using a TA-XT2 texture analyser (Stable Micro Systems, Surrey, UK). Gel in the canister (with a dimension of $37 \mathrm{~mm}$ in diameter and 20 $\mathrm{mm}$ in height) was compressed at a speed of $1.0 \mathrm{~mm} / \mathrm{s}$ to a distance of $10.0 \mathrm{~mm}$ with a stainless steel punch probe $6.0 \mathrm{~mm}$ in diameter. The maximum force peak in the TPA profile represented the gel hardness [11].

\section{Statistical analysis}

Values were expressed as mean with standard deviation of triplicate determinations. Data was analyzed by analysis of variance (ANOVA) using Statistical Analysis System (SAS) [12]. Differences among samples were considered significant at $\mathrm{p}<0.05$.

\section{Results and Discussion}

Means of damaged starch content, average particle size and gel hardness of dry, semi-wet and wet ground flours were summarized in Table 1. The damaged starch levels for the rice flour samples varied from $3.24 \%$ to $13.07 \%$. Wet grinding process produced flour with significantly $(\mathrm{p}<0.05)$ lowest percentage of damaged starch while dry ground flour exhibits the highest. The high percentage of damaged starch in dry ground flour is likely attributable to damage produced by the shears force and the heat during grinding [13] as the rice grains were directly ground as it is, whereby the hammer mill pressed the grains against an abrasive ring at high rotating speed to break the grain structure. In addition, high damaged starch also due to the higher grain hardness of dry grinding technique compared to others since there is no soaking step in the process that eventually provides softening effect to the rice kernels [14]. Starch damage profoundly changes starch granule structure and it influences functional properties of starch [15].

Particle size of flour, measured as the mean particle diameter, is a critical factor in determining the flour's usefulness and application in further processing [16]. Figure 1 shows the particle size distributions of dry, semi-wet and wet ground flour samples. The curves showed two distinct types among the rice flour samples: dry and semiwet ground vs wet ground flour. Dry and semi-wet ground flours showed unimodal distributions while wet ground flour displayed bimodal distributions. The wet ground flour showed to distinct peaks consisted of two particle types, with size of 2-20 $\mu \mathrm{m}$ and 20-106 $\mu \mathrm{m}$. Significant differences were found $(\mathrm{p}<0.05)$ in the average flour particle diameter for each sample (Table 1). Average particle size of flours ranged from 9.70 to $51.44 \mu \mathrm{m}$, with wet ground 
flour composed of the finest average particle size as compared to others. Though dry ground rice flour yield flour with smaller average particle size when compared with semi-wet ground flour, but the former exhibit significantly $(p<0.05)$ highest damaged starch. This is supported by Nishita and Bean [17] that claimed in dry milling, a high percentage of damaged starch was associated with finer particles. Nevertheless, the average particle size of dry ground rice flour obtained in this study was smaller $(39.4 \mu \mathrm{m})$ than findings reported by Hossen et al.[18] of hammer-milled flour $(72.3-141.2 \mu \mathrm{m})$, due to different manners in the technique. Noomhorn et al. [19] claimed that the starch granules of smaller rice particles are more resistant to swelling than those of larger particles and thus affecting the RVA measurement $[20,21]$ as it caused a decrease in peak viscosity. The peak viscosity of fine wet ground flour was significantly $(\mathrm{p}<0.05)$ lower as compared to others, confirming the reports of Bryant et al. [22].

Table 1. Starch damage contents, average particle size distribution and gel hardness of dry, semi-wet and wet ground rice flours

\begin{tabular}{lccc}
\hline Grinding Process & $\begin{array}{c}\text { Starch Damage } \\
(\boldsymbol{\%})\end{array}$ & $\begin{array}{c}\text { Average Particle Size } \\
(\mathbf{u m})\end{array}$ & $\begin{array}{c}\text { Gel Hardness } \\
(\mathbf{g})\end{array}$ \\
\hline Dry Grinding & $13.07 \pm 0.03^{\mathrm{a}}$ & $39.37 \pm 0.14^{\mathrm{b}}$ & $13.65 \pm 0.05^{\mathrm{b}}$ \\
Semi-Wet Grinding & $4.85 \pm 0.03^{\mathrm{b}}$ & $51.44 \pm 0.13^{\mathrm{a}}$ & $13.70 \pm 0.11^{\mathrm{b}}$ \\
Wet Grinding & $3.24 \pm 0.03^{\mathrm{c}}$ & $9.70 \pm 0.17^{\mathrm{c}}$ & $16.62 \pm 0.07^{\mathrm{a}}$ \\
\hline
\end{tabular}

Mean values with the same superscript letters within a column are not significantly different at $\mathrm{p}>0.05$
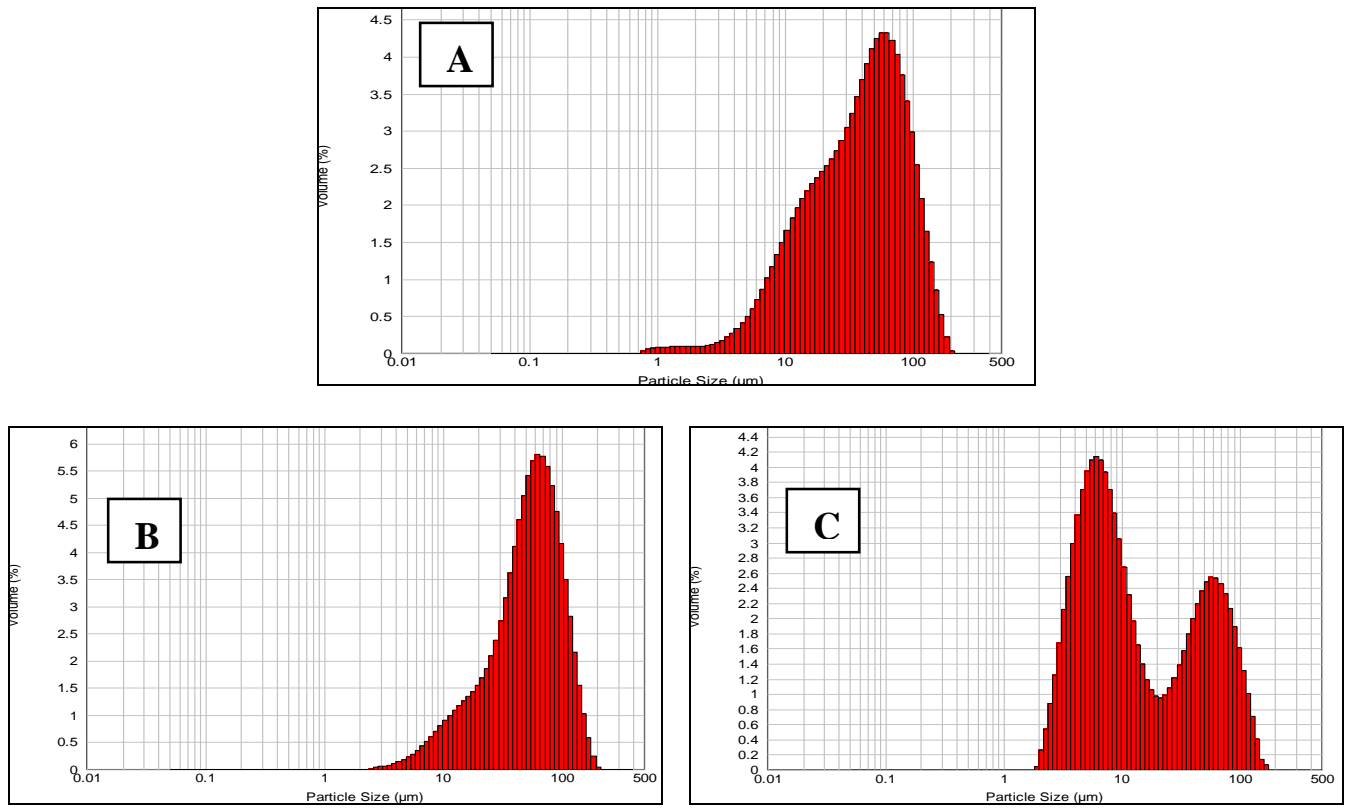

Figure 1. Particle size distributions of dry (A), semi-wet (B) and wet (C) ground rice flours

Scanning electron microscopy was used to observe the submicroscopic shape and surface characteristic of flour particles (Figure 2). Scanning electron micrographs of all flours showed irregular pentagonal or hexagonal shaped particles with protein matrix. Wet ground flour contains more free starch granules and smaller particles, plus more material adheres to the starch granules. On the other hand, some damaged granules were viewed in the dry ground 
flour. As observed by Santhi and Poongodi [23], rice consists of several polyhedral starch granules in a single amyloplast and rice starch granules are the smallest of the starch grains produced by plants $(3.8 \mu \mathrm{m})$ [24].
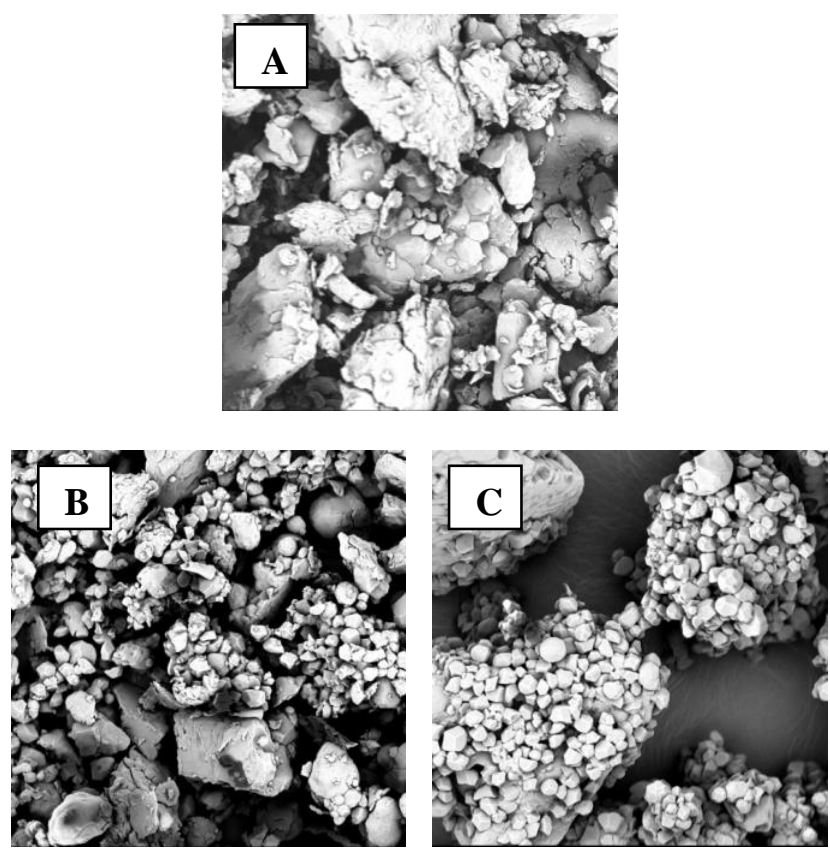

Figure 2. Microscopic structure of dry (A), semi-wet (B) and wet (C) ground rice flours

Hardness was derived from texture profile analysis curve with the starch gel from wet ground flour showed the highest hardness $(16.62 \mathrm{~g})$, whereas there is no significant difference ( $p>0.05)$ between dry and semi-wet ground flour samples. Starches that exhibit harder gels tend to have higher amylose content and longer amylopectin chains [25]. It is also associated with starch gel retrogradation, along with the crystallisation of amylose in a short time which leads to harder gels [26]. Miles et al. [27] also claimed that rigidity of starch gel is highly dependent on retrogradation of gelatinised starch granules, syneresis of water and crystallisation of amylopectin. Therefore, presence of certain level of soluble carbohydrates from wet ground flour could enhance starch gel retrogradation that would give rise to harder gels [28].

Pasting property is one of the most important properties that influence quality and aesthetic considerations in the food industry as they affect texture and digestibility as well as the end use of starch-based food commodities [29]. Pasting profile results from a complex interaction of the test material and water, affected by temperature and time, and it was performed using the rapid visco analyzer (RVA). The plot of viscosity of the flour samples against heating time was shown in Figure 3. Significant differences were found $(p<0.05)$ at each parameter of the RVA curve, except the pasting temperature (Table 2).

Peak viscosity is an index of the ability of starch-based food to swell freely before their physical breakdown [30]. The value ranged from $2777.67-2834.67$ centipoise $(\mathrm{cP})$. Dry ground flour had significantly ( $<<0.05)$ highest peak viscosity followed by semi-wet and wet ground flour. High peak viscosity indicates high starch content [31] and is an indicative that the flour may be suitable for products requiring high gel strength and elasticity [32,33] The peak viscosity of wet ground flour was significantly low $(\mathrm{p}<0.05)$ compared to other samples and this indicates that the carbohydrate components of wet ground flour will not breakdown easily and quickly like the other samples until it is cooked properly [34]. 
Noorlaila et al: EFFECTS OF DIFFERENT GRINDING METHODS ON MORPHOLOGICAL, TEXTURAL PROPERTIES AND PASTING PROFILES OF MR220 RICE FLOUR

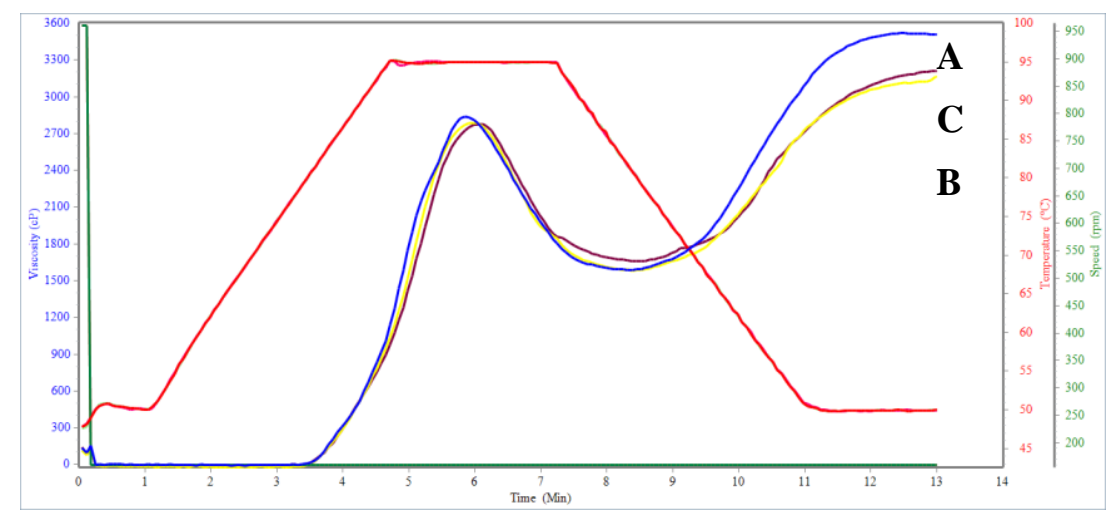

Figure 3. Pasting profiles of dry (A), semi-wet (B) and wet (C) ground rice flours

Table 2. Pasting profiles of dry, semi-wet and wet ground rice flours

\begin{tabular}{lccc}
\hline Pasting Viscosity $(\mathbf{c P})$ & Dry Grinding & Semi-Wet Grinding & Wet Grinding \\
\hline Peak Viscosity & $2834.67 \pm 6.51^{\mathrm{a}}$ & $2798.67 \pm 10.12^{\mathrm{b}}$ & $2777.67 \pm 6.51^{\mathrm{c}}$ \\
Trough & $1602.00 \pm 13.75^{\mathrm{ab}}$ & $1582.00 \pm 45.00^{\mathrm{b}}$ & $1656.67 \pm 9.71^{\mathrm{a}}$ \\
Breakdown & $1232.67 \pm 17.24^{\mathrm{a}}$ & $1216.67 \pm 45.63^{\mathrm{a}}$ & $1121.00 \pm 16.09^{\mathrm{b}}$ \\
Final Viscosity & $3548.67 \pm 44.19^{\mathrm{a}}$ & $3153.00 \pm 8.19^{\mathrm{b}}$ & $3195.00 \pm 22.52^{\mathrm{b}}$ \\
Setback & $1946.67 \pm 37.86^{\mathrm{a}}$ & $1571.00 \pm 39.96^{\mathrm{b}}$ & $1538.33 \pm 13.61^{\mathrm{b}}$ \\
Pasting Temperature $\left({ }^{\circ} \mathrm{C}\right)$ & $80.37 \pm 0.45^{\mathrm{a}}$ & $80.42 \pm 0.54^{\mathrm{a}}$ & $80.15 \pm 0.57^{\mathrm{a}}$ \\
\hline
\end{tabular}

Mean values with the same superscript letters across the row are not significantly different at $\mathrm{p}>0.05$

The ability of paste to resist breakdown during cooling is indicated by trough viscosity [35]. Trough is the minimum viscosity value in the constant temperature phase of the pasting profile [31]. The value ranged between $1582.00-$ $1656.67 \mathrm{cP}$; with sample of semi-wet flour having the lowest value and wet ground flour having the highest value. Breakdown viscosity measured the starch paste resistance to heat and shear [8], while setback viscosity exhibited the tendency of starch pastes to retrograde, which is an index of starch retrogradation [36]. The breakdown value ranged from 1121.00 to $1232.67 \mathrm{cP}$ while the setbacks ranged from 1538.33 to $1946.67 \mathrm{cP}$. Referring toTable 2, breakdown of dry and semi-wet ground flour was similar $(p>0.05)$, but was significantly $(p<0.05)$ higher than wet ground flour. The rate of the breakdown is dependent on temperature, shear stress applied to the system, and the nature of the starch tested [37]. Decrease in breakdown would cause less amylose molecules leached out into the matrix during cooking. Ultimately this could result in reduced retrogradation of amylose molecules [38]. High values in breakdown and low values in setback of semi-wet ground flour are indicative of high cooking quality since neither the cooked rice retrogrades nor becomes stiff upon cooling [39].

Final viscosity is commonly used to define the quality of particular starch-based flour, since it indicates the ability of the flour to form a viscous paste after cooking and cooling [35]; measure as the change in the viscosity after holding cooled starch at $50{ }^{\circ} \mathrm{C}$ [40]. It also represents the re-association of starch granules especially amylose during cooling time after gelatinization and the formation of gel network [41]. The final viscosity value recorded from this study ranged from 3153.00 to $3548.67 \mathrm{cP}$. Final viscosity, as well as setback viscosity values of dry ground flour were significantly $(\mathrm{p}<0.05)$ higher than semi-wet and wet ground flour. The lower final viscosity of flours displayed the extension of the effect on the amylose chains, which might lose the ability to retrograde during 
cooling due to their fragmentation [42], in this case, may due to mechanism involved in hammer mill when rice grains subjected to semi-wet grinding process.

Pasting temperature is the temperature at which the viscosity of the starch pastes begins to rise; indicates the minimum temperature required in cooking the sample [43].The pasting temperature ranged between $80.15{ }^{\circ} \mathrm{C}$ and $80.42{ }^{\circ} \mathrm{C}$. There were no significant differences $(\mathrm{p}>0.05)$ in pasting temperature among all the samples. These values are comparatively low as compared with values having been reported in a number of rice pasting studies e.g., $86{ }^{\circ} \mathrm{C}$ in long grain [44] and $90-95{ }^{\circ} \mathrm{C}$ in cryomilled and hammer milled rice [30, 35]. The attainment of the pasting temperature is essential in ensuring swelling, gelatinization and subsequent gel formation during processing [11]. Lower pasting temperatures were found to be associated with faster particle swelling and higher peak viscosity [45] while higher pasting temperatures indicates higher water binding capacity, higher gelatinization tendency and lower swelling properties of starch based flour due to high degree of association between starch granules [46]. The difference in damaged starch content and particle size distribution between flours is reported to affect the RVA profile [47]. Damaged starch granules can absorb water, swell and leach out amylose and amylopectin, which causes an increase in the viscosity of starch [48].

\section{Conclusion}

Dry, semi-wet and wet grinding techniques involved in rice flour production significantly $(\mathrm{p}<0.05)$ affects the percentage of damaged starch, average particle size distribution, gel hardness and pasting profiles parameters except the pasting temperature. Wet grinding process exhibit flour of lowest amount of damaged starch granules $3.24 \%$ with finest average particle size of $9.70 \mathrm{um}$. Flour samples had similar pattern of viscosity curves, but samples of dry ground flour showed significantly $(\mathrm{p}<0.05)$ higher final viscosity. Overall, the findings suggest that wet grinding process can be regarded as the potential flour grinding practice since it produces flour with lowest starch damage, and finest average particle size as compared to others. Nevertheless, grinding method to be considered in producing the flour and to be utilized in rice based food products is depending on the specific uses.

\section{Acknowledgement}

The authors thank Universiti Teknologi MARA, Research Management Institute Universiti Teknologi MARA, Universiti Sains Malaysia and Malaysian Agricultural Research and Development Institute for the support and assistance throughout this research.

\section{References}

1. Wahab, A. G. and Rittgers, C. (2014). Global Agricultural Information Network Report MY4001 - Grain \& Feed Annual, Malaysia. (No.: MY4001), pp 1-5.

2. Hossain, M. S., Singh, A. K. and Fasih-uz-Zaman. (2009). Cooking and eating characteristics of some newly identified inter sub-specific (Indica/Japonica) Rice Hybrids. Science Asia, 35: 320 - 325.

3. Bhattacharya, K. R. (2009). Physicochemical basis of eating quality of rice. Cereal Foods World, 54 (1): 18 28.

4. Song, S. -H., Lee, M. -G., Lee, H. -J. and Yoon, W. -B. (2014). Analysis of grinding kinetics to control the effect of rice flour particle size on the yield of alcohol and glucose during fermentation. International Journal of Food Science \& Technology: $1-8$.

5. Djantou, E. B., Mbofung, C. M., Scher, J. and Desobry, S. (2007). A modelling approach to determine the effect of pre-treatment on the grinding ability of dried mangoes for powder production (Mangifera indica var kent). Journal of Food Engineering, 80: 668 - 677.

6. Pauly, A., Pareyt, B., Fierens, E. and Delcour, J. A. (2013). Wheat (Triticum aestivum L. and T. turgidum L. ssp. durum) kernel hardness: ii. implications for end-product quality and role of puroindolines therein. Comprehensive Reviews in Food Science \& Food Safety, 12 (4): 427 - 438.

7. Winger, M., Khouryieh, H., Aramouni, F. and Herald, T. (2014). Sorghum flour characterization and evaluation in gluten-free flour tortilla. Journal of Food Quality, 1 - 12.

8. Kong, X., Zhu, P., Sui, Z. and Bao, J. (2015). Physicochemical properties of starches from diverse rice cultivars varying in apparent amylose content and gelatinisation temperature combinations. Food Chemistry, 172: 433 440 . 
Noorlaila et al: EFFECTS OF DIFFERENT GRINDING METHODS ON MORPHOLOGICAL, TEXTURAL PROPERTIES AND PASTING PROFILES OF MR220 RICE FLOUR

9. American Association of Cereal Chemists. (2000). AACC Method 76-31. In Approved Methods of AACC, $10^{\text {th }}$ Ed., St. Paul, MN.

10. American Association of Cereal Chemists. (2000). AACC Method 61-02. In Approved Methods of AACC, $10^{\text {th }}$ Ed., St. Paul, MN.

11. Hasjim, J., Li, E. and Dhital, S. (2013). Milling of rice grains: effects of starch/flour structures on gelatinization and pasting properties. Carbohydrate Polymer, 92: $682-690$.

12. Statistical Analysis System. (2002). SAS: User's Guide Statistics, (Version 9.13). SAS Institute, Inc., Cary, NC.

13. Hossen, M. S., Sotome, I., Takenaka, M., Isobe, S., Nakajima, M. and Okadome, H. (2011). Effect of particle size of different crop starches and their flours on pasting properties. Japan Journal of Food Engineering, 12 (1): $29-35$.

14. Ngamnikom, P. and Songsermpong, S. (2011). The effects of freeze, dry, and wet grinding processes on rice flour properties and their energy consumption. Journal of Food Engineering, 104: 632 - 638.

15. Cai, L., Choi, I., Hyun, J.-N. and Jeong, B.-K. (2014). Influence of bran particle size on bread baking quality of whole grain wheat flour and starch retrogradation. Cereal Chemistry, 91 (1): $65-71$.

16. Patwa, A., Malcolm, B., Wilson, J. and Ambrose, R. P. K. (2014). Particle size analysis of two distinct classes of wheat flour by sieving. American Society of Agricultural \& Biological Engineers, 57 (1): 151 - 159.

17. Nishita, K. D. and Bean, M. M. (1982). Grinding methods: their impact on rice flour properties. Cereal Chemistry, 59 (1): $46-49$.

18. Hossen, M. S., Sotome, I., Takenaka, M., Isobe, S., Nakajima, M. and Okadome, H. (2011). Starch damage and pasting properties of rice flours produced by dry jet grinding. Cereal Chemistry, 88 (1): 6-11.

19. Noomhorn, A., Kongseree, N. and Apintapong, N. (1997). Effect of aging on the quality of glutinous rice crackers. Cereal Chemistry, 74: $12-15$.

20. Bryant, R. J., Kadan, R. S., Champagne, E. T., Vinyard, B. T. and Boykin, D. (2001). Functional and digestive characteristics of extruded rice flour. Cereal Chemistry, 78: $131-137$.

21. Park, J. H., Kim, D. C., Lee, S. E., Kim, O. W., Kim, H., Lim, S. T. and Kim, S. S. (2014). Effects of rice flour size fractions on gluten free rice bread. Food Science Biotechnology, 23 (6): 1875 - 1883.

22. Song, J. Y. and Shin, M. S. (2007). Effects of soaking and particle sizes on the properties of rice flour and gluten-free rice brad. Food Science Biotechnology, 16: 759 - 764.

23. Santhi, K. and Poongodi, V. T. (2014). Physical and functional characteristics of milling fractions of indian kavun pigmented brown rice (oryza sativa 1.). International Journal of Agricultural \& Food Science, 4 (2): 78 83.

24. Zhongkai, Z., Kevin, R., Stuart, H. and Chris, B. (2002). Composition and functional properties of rice. International Journal Food Science Technology, 37: 849 - 868.

25. Wang, L., Xie, B., Shi, J., Xue, S., Deng, Y., Wei, Y. and Tian, B. (2010). Physicochemical properties and structure of starches from chinese rice cultivars. Food Hydrocolloids, 24: $208-216$.

26. Mir, S. A. and Bosco, S. J. D. (2014). Cultivar difference in physicochemical properties of starches and flours from temperate rice of Indian Himalayas. Food Chemistry, 157: 448 - 456.

27. Miles, M. J., Morris, V. J., Orford, P. D. and Ring, S. G. (1985). The roles of amylose and amylopectin in the gelation and retrogradation of starch. Carbohydrate Research, 135: $271-281$.

28. Chang, S. M. and Liu, L. C. (1991). Retrogradation of rice starches studied by differential scanning calorimetry and influence of sugars, $\mathrm{NaCl}$ and lipids. Journal of Food Science, 56: $564-566$.

29. Onabanjo, O. O. and Ighere Dickson, A. (2014). Nutritional, functional and sensory properties of biscuit produced from wheat-sweet potato composite. Journal of Food Technology Research, 1 (3): 111 - 121.

30. Adebowale, A. A., Sanni, L. O. and Onitilo, M. O. (2008). Chemical composition and pasting properties of tapioca grit from different cassava varieties and roasting method. African Journal of Food Science, 2: 77 - 82.

31. Adegunwa, M. O., Ganiyu, A. A., Bakare, H. A. and Adebowale, A. A. (2014). Quality evaluation of composite millet-wheat chinchin. Agriculture \& Biology Journal of North America, 5 (1): 33 - 39.

32. Regena, J. K. and Chen, Z. (2009). Physic-chemical properties of peanut meal flour as affected by processing methods. Journal of Biochemistry, 34: 229 - 243.

33. Ikegwu, O. J., Okechukwu, P. E. and Ekumankana, E. O. (2010). Physic-chemical and pasting characteristics of flour and starch from achi (brachystegiaeunycoma) seed. Journal of Food Technology, 8 (2): 58 - 66.

34. Obadina, A. O., Babatunde, B. O. and Olotu, I. (2014). Changes in nutritional composition, functional, and sensory properties of yam flour as a result of presoaking. Food Science \& Nutrition, $1-6$. 
35. Adebowale, A. A., Adegoke, M. T., Sanni, S. A., Adegunwa, M. O. and Fetuga, G. O. (2012). Functional properties and biscuit making potentials of sorghum-wheat flour composite. American Journal of Food Technology, 7: $372-379$.

36. Liang, X. and King, J. M. (2003). Pasting and crystalline property differences of commercial and isolated rice starch with added amino acids. Journal of Food Science, 68: 832 - 838.

37. Newport Scientific. (1998). Interpretation. In Applications Manual for the Rapid Visco Analyzer, Australia, Newport Scientific Pty. Ltd., pp 13 - 16.

38. Sharma, R., Oberoi, D. P. S., Sogi, D. S. and Gill, B. S. (2009). Pasting and crystalline property differences of commercial and isolated rice starch with added amino acids. Journal of Food Processing \& Preservation, 33: $401-414$

39. Asante, M. D., Offei, S. K., Gracen, V. Adu-Dapaah, H., Danquah, E. Y., Bryant, R. and McClung, A. (2013). Starch physicochemical properties of rice accessions and their association with molecular markers. Starch / Starke, 65: 1022 - 1028.

40. Danbaba, N., Ukwungwu, M. N., Maji, A. T., Ndindeng, S. A., Jiya, A. G., Danfulani, S. and On, E. N. (2014). End-use quality of upland NERICA rice (Oryza sativa $\mathrm{L}$ ) as affected by the addition of sweet cassava (low cyanide, Manihotesculenta) flour. International Journal of Agriculture \& Forestry, 4 (3): 237 - 245.

41. Chanapamokkhot, H. and Thongngam, M. (2007). The chemical and physicoc-chemical properties of sorghum starch and flour. Journal of Natural Science, 41: $343-349$.

42. Martinez, M. M., Calvino, A., Rosell, C. M. and Gomez, M. (2014). Effect of different extrusion treatments and particle size distribution on the physicochemical properties of rice flour. Food Bioprocess Technology, 7: 2657 -2665 .

43. Kaur, S., Singh, N., Sodhi, N. S. and Rana, J. C. (2009). Diversity in properties of seed and flour of kidney bean germplasm. Food Chemistry, 117: $282-289$.

44. Chung, H., Liu, Q., Huang, R., Yin, Y. and Li, A. (2010). Physicochemical properties and in vitro starch digestibility of cooked rice from commercially available cultivars in Canada. Cereal Chemistry, 87 (4): 297 304.

45. Offia-Olua, B. I. (2014). Chemical, functional and pasting properties of wheat (Triticumspp)-walnut (Juglansregia) flour. Food \& Nutrition Sciences, 5: 1591 - 1604.

46. Liu, L., Herald, T. J., Wang, D., Wilson, J. D., Bean, S. R. and Aramouni, F. M. (2012). Characterization of sorghum grain and evaluation of sorghum flour in a Chinese egg noodle system. Journal of Cereal Science, 55: $31-36$.

47. Ashida, K. (2014). Properties of floury rice mutant and its utilization for rice flour. Japan Agricultural Research Quarterly, 48 (1): 51 - 56.

48. Barrera, G. N., Bustos, M. C., Iturriaga, L., Flores, S. K., Leon, A. E. and Ribotta, P. D. (2013). Effect of damaged starch on the rheological properties of wheat starch suspensions. Journal of Food Engineering, 116: $233-239$. 